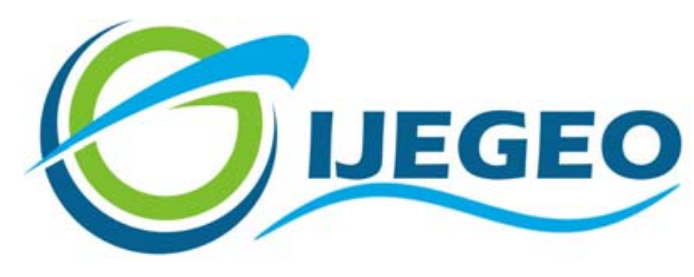

International Journal of Environment and Geoinformatics (IJEGEO) is an international, multidisciplinary, peer reviewed, open access journal.

\title{
Comparison of Pixel-Based and Object-Based Classification Methods in Determination of Wetland Coastline
}

\author{
Adalet DERVISOGLU, Baha B. BILGILIOGLU, Nur YAGMUR
}

\author{
Chief in Editor \\ Prof. Dr. Cem Gazioğlu \\ Co-Editor
}

Prof. Dr. Dursun Zafer Şeker, Prof. Dr. Şinasi Kaya,

Prof. Dr. Ayşegül Tanık and Assist. Prof. Dr. Volkan Demir

Editorial Committee (April 2020)

\begin{abstract}
Assos. Prof. Dr. Abdullah Aksu (TR), Assit. Prof. Dr. Uğur Algancı (TR), Prof. Dr. Bedri Alpar (TR), Prof. Dr. Lale Balas (TR), Prof. Dr. Levent Bat (TR), Prof. Dr. Paul Bates (UK), İrşad Bayırhan (TR), Prof. Dr. Bülent Bayram (TR), Prof. Dr. Luis M. Botana (ES), Assos. Prof. Dr. Gürcan Büyüksalih (TR), Prof. Dr. Nuray Çağlar (TR), Prof. Dr. Sukanta Dash (IN), Dr. Soofia T. Elias (UK), Prof. Dr. A. Evren Erginal (TR), Assoc. Prof. Dr. Cüneyt Erenoğlu (TR), Dr. Dieter Fritsch (DE), Prof. Dr. Çiğdem Göksel (TR), Prof.Dr. Lena Halounova (CZ), Prof. Dr. Manik Kalubarme (IN), Dr. Hakan Kaya (TR), Assist. Prof. Dr. Serkan Kükrer (TR), Assoc. Prof. Dr. Maged Marghany (MY), Prof. Dr. Michael Meadows (ZA), Prof. Dr. Nebiye Musaoğlu (TR), Prof. Dr. Masafumi Nakagawa (JP), Prof. Dr. Hasan Özdemir (TR), Prof. Dr. Chryssy Potsiou (GR), Prof. Dr. Erol Sarı (TR), Prof. Dr. Maria Paradiso (IT), Prof. Dr. Petros Patias (GR), Prof. Dr. Elif Sertel (TR), Prof. Dr. Nüket Sivri (TR), Prof. Dr. Füsun Balık Şanlı (TR), Prof. Dr. Uğur Şanlı (TR), Duygu Ülker (TR), Prof. Dr. Seyfettin Taş (TR), Assoc. Prof. Dr. Ömer Suat Taşkın (US), Dr. İnese Varna (LV), Dr. Petra Visser (NL), Prof. Dr. Selma Ünlü (TR), Assoc. Prof. Dr. İ. Noyan Yilmaz (AU), Prof. Dr. Murat Yakar (TR), Assit. Prof. Dr. Sibel Zeki (TR)
\end{abstract}

Abstracting and Indexing: TR DIZIN, DOAJ, Index Copernicus, OAJI, Scientific Indexing Services, International Scientific Indexing, Journal Factor, Google Scholar, Ulrich's Periodicals Directory, WorldCat, DRJI, ResearchBib, SOBIAD 


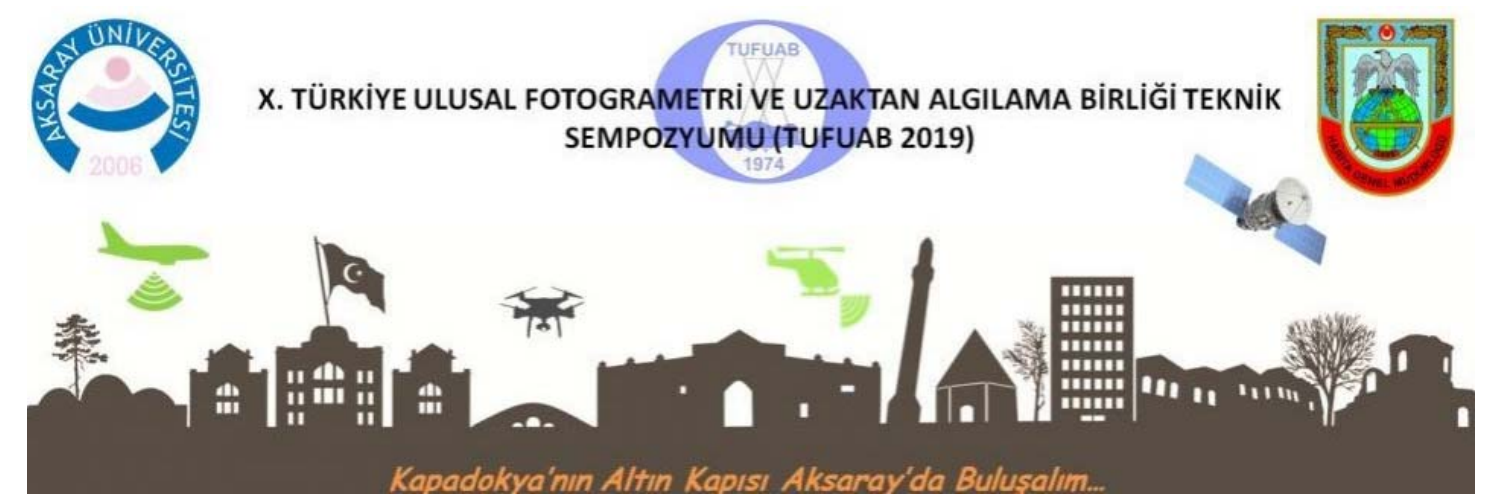

Dear colleagues and friends,

X. TUFUAB Technical Symposium was held in Aksaray on 25-27, April 2019. The Symposium was carried out by the organizations of Aksaray University and General Directorate of Mapping. As a international symposium in the field of photogrammetry and remote sensing, X.TUFUAB Technical Symposium 2019 is devoted to promote the advancement of knowledge, research, development, education and training in Geographical Information Sciences, Information Technology, Environmental Management and Resources, Sustainable Agriculture, Surveying, Photogrammetry and Remote Sensing, their integration and applications, as to contribute to the well-being of humanity and the sustainability of the environment. 425 participants and scientists from 7 countries were attended to this symposium. 125 oral presentations and 10 poster presentations were presented during the symposium. 135 presentations take place in 25 sessions in two days.

The presentations were reviewed by the scientific committee. Nine of these presentations were found worthy to be published in "International Journal of Environment and Geoinformatics (IJEGEO)" by the scientific committee. We would like to thank editorial board of IJEGEO for the publication of these works in the symposium.

Aksaray, Turkey, April 2019.

Prof. Dr. H. Murat YILMAZ

Chair of the Organizing Committee
Dr. Eng. Tuğg. Oman ALP

Director, General Directorate of Mapping 


\title{
Comparison of Pixel-Based and Object-Based Classification Methods in Determination of Wetland Coastline
}

\author{
Adalet Dervisoglu ${ }^{1 *}$ (D) , Baha B. Bilgilioglu ${ }^{1,2}$ iD , Nur Yagmur ${ }^{1}$ \\ ${ }^{1}$ ITU, Civil Engineering Faculty, Geomatics Engineering Department, Maslak Istanbul, TR \\ ${ }^{2}$ Gümüşhane University, Engineering Faculty, Geomatics Engineering Department, Gümüşhane, TR \\ * Corresponding author: A. Dervisoglu \\ E-mail: adervisoglu@itu.edu.tr
}

How to cite: Dervisoglu et al, (2019). Comparison of Pixel-Based and Object-Based Classification Methods in Determination of Wetland Coastline. International Journal of Environment and Geoinformatics (IJEGEO), 7(2):213-220. DOI:10.30897/ijegeo. 713307

\begin{abstract}
Tuz Lake and its surrounding lakes (Tersakan Lake, Duden Lake, Bolluk Lake, Esmekaya Lake, Kopek Lake, Akgol) are placed in the Central Anatolia region. These lakes maintain the ecosystem's integrity and make a good habitat for numerous bird species, especially flamingos. The Duden Lake is located within the boundaries of the Tuz Lake Special Environmental Protection Area and was declared as a protected area in 1992. The surface and underground water around Kulu District of Konya feed the Duden Lake, which is tectonically formed through the Kulu Stream. The lake with the average area of 860 hectares is unfortunately at the risk of extinction. Remote sensing has been the most useful tool to obtain spatial and temporal information about wetlands and it provides up-to-date, accurate, and cost-effective information. Remote sensing methods and applications are used quite effectively on wetlands. The traditional pixel-based classification method is applied to different satellite images in wetlands over many decades, and the usage of object-based classification method has started recently comparing to the pixel-based one. This study aimed to determine the coastline of the wetlands. Sentinel 2 satellite images, which provide free access and high spatial resolution, are used to observe the coastline of Duden Lake through the usage of pixel-based and object-based classification methods in all the seasons. The applicability of the methods in the determination of shallow wetland coastline is studied and evaluated. The results of the pixel-based and the object-based classification images are compared by accuracy assessment.
\end{abstract}

Keywords: Coastline, Classification, Wetland, Remote sensing, Pixel-based, Object-based, Duden Lake

\section{Introduction}

The coastline is defined as a line that forms the boundary between land, sea, or lake. Remote sensing has been widely used for coastline mapping and extraction. Due to the dynamic structure of wetlands and mixed pixels in especially shallow water covering marsh environments, delineation of wetland coastline is quite difficult (Alesheikh et al., 2007; Burak et al., 2004; Bayram ety al., 2004; Kalkan, et al., 2019; Celik and Gazioglu, 2020). There are various methods which are applied on optical imagery such as single-band threshold method, water index method, unsupervised and supervised classification methods to delineate the coastline of wetlands (Haibo et al., 2011). The coastline can be extracted from a single band image for obtaining a rapid coastline extraction. The reflectance of water is nearly equal to zero in infrared bands and reflectance of land covers is greater than water. The absorption of infrared bands in water is high, enabling to separate water and land. Another simple land/water separation method is to use the band ratio. The ratio between red and infrared bands is greater than 1 for water, and less than 1 for land in large areas of the coastal zone.

Water indices can be used for land/water discrimination. Normalized Difference Water Index (NDWI) has been widely used for water body extraction (Lillesand et al., 2014). NDWI can be applied to images as pixel-based and object-based. Kaplan and Avdan (2017) applied NDWI with object-based methods to Sentinel 2 satellite images and determined that object-based NDWI shows better results comparing to pixel-based NDWI.

The coastline can be determined by pixel-based classification and object-based classification methods. Guariglia et al. (2006) used the ISODATA unsupervised classification and band ratio methods for coastline mapping and identification of shoreline changes. Li and Damen (2010) detected the coastline change of the Pearl River Estuary using a supervised classification in 1979, 1990, 2000, and 2003. Shang et al. (2012) and Kaya et al. (2019) used the maximum likelihood supervised classification method to extract information from coastal wetlands between 2007 and 2010. Rasuly et al. (2010) used object-oriented techniques for monitoring the Caspian Sea coastline changes from optical imageries. Dronova et al. (2011) used object-based classification methods to determine change detection of the Poyang Lake during the 2007-2008 low water seasons. Kalkan et al. (2013) compared the pixel and object-based classification methods on Landsat 8 imagery and observed that both of these methods are applicable in the extraction of the coastlines. 
In this study, Duden Lake which is a shallow wetland was chosen as the study area. Coastline change of Duden Lake was determined seasonally by different methods in a one-year period. For the delineation of wetland coastline, pixel and object-based classification methods were applied to Sentinel 2 satellite images. Besides, NDWI which is the most used water index in the literature was applied to pixel-based and object-based images, results compared with each other, and the classifications.

\section{Study Area}

The total natural wetland area in Turkey is about $2.3 \%$ of the country's surface area, and there are 17269 natural wetlands. 921 of these wetlands have a size greater than 8 hectares, having 1714792 hectares of the area in total, and constitute $99.48 \%$ of the overall wetland areas

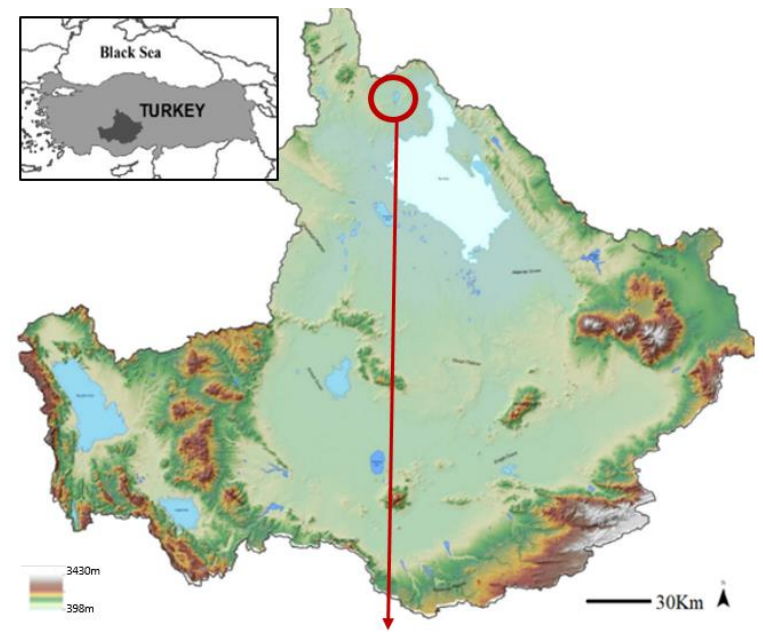

(Doganyigit, 2016). Konya Closed Basin is one of Turkey's 25 hydrological basins and the Duden Lake located in this basin has a surface area of about 850 ha. The lake is tectonically formed and the sources feeding the lake are precipitation and Degirmenozu/Kulu creek. In Duden Lake, which houses 185 bird species and most of them are flamingos; the habitat of birds has started to shrink due to uncontrolled irrigation and drought that started due to global warming. The water surface area and boundaries have been changing in the shallow wetland area of Duden during the year, and a large area has been dried in summer. It was declared as a protected area in 1992 and it is within the boundaries of Tuz Lake Special Environmental Protection Area. It is a birdwatching area due to its wildlife and is in danger of extinction. The location of the Duden Lake which is chosen as the study area is given in Figure 1.

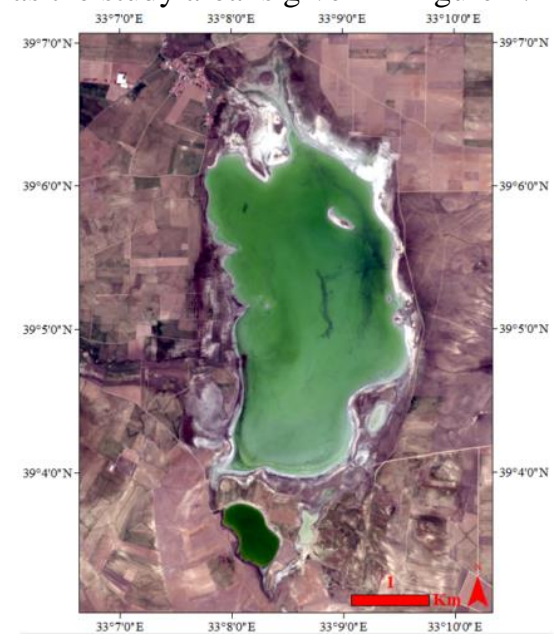

Figure 1. Konya Closed Basin and location of the Duden Lake.

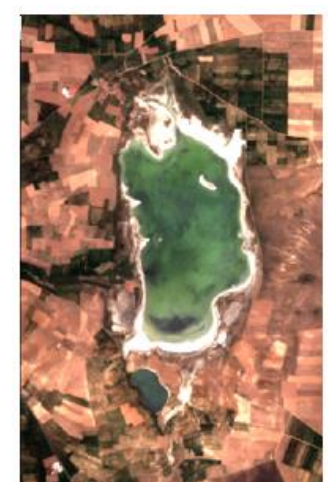

March 28, 2018

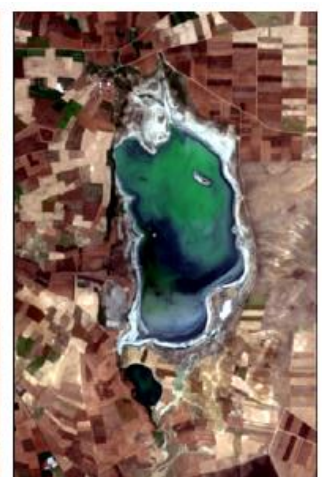

June 28,2018

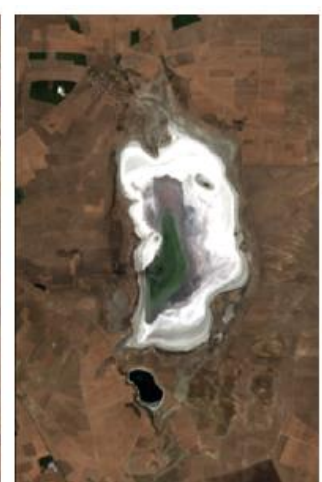

September 29, 2018

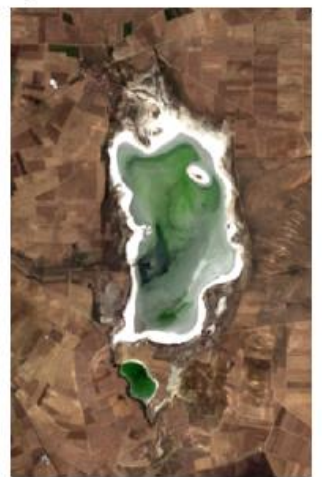

November 08, 2018

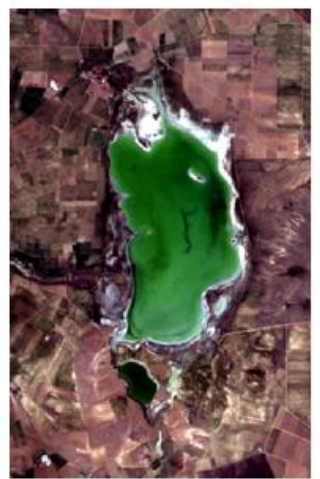

March 18, 2019

Figure 2. Sentinel 2 MSI images (RGB:4/3/2) used in the study. 


\section{Data and Methodology}

In this study, Sentinel 2 MSI Satellite images were used to detect the water surface area, and thus the coastline has also been determined. Sentinel 2 MSI Satellites (A and $B$ ) have four bands at the spatial resolution of $10 \mathrm{~m}$ (Band 2, Band 3, Band 4 and Band 8), six bands at the spatial resolution of $20 \mathrm{~m}$ (Band 5, Band 6, Band 7, Band 8a, Band 11 and Band 12) and three bands at the spatial resolution of $60 \mathrm{~m}$ (Band 1, Band 9 and Band 10). The radiometric resolution is 12-bit, and the temporal resolution is 5 days at the equator. Five Sentinel 2 MSI satellite images were used between March 2018 and March 2019 to see the changes in the surface area and the coastline of the water in one year. Used satellite images are given in Figure 2. Kulu meteorological station data (temperature, precipitation, evaporation) were used in the wetland to examine the seasonal change in water surface area.

Two different classification methods, pixel-based and object-based classifications, were used for each image to reach the water surface areas, in this study. Accuracy assessment analysis of each classification was performed, and then the determined water surface areas were converted to vector. The vector data of the coastal lines obtained from both classification methods were compared for each month.

The NDWI is the most appropriate and widely used index for water body mapping. The water body has strong absorbability and low radiation in the range from visible to infrared wavelengths. The index uses the green and Near-Infrared bands of remote sensing images based on this phenomenon The NDWI can enhance the water information effectively in most cases. Results changes between -1 and 1 and values that are greater than zero show the water area (McFeeters, 1996). NDWI was applied to both pixel and segmented images and compared them with classification results. Flowchart of the study is given in Figure 3.

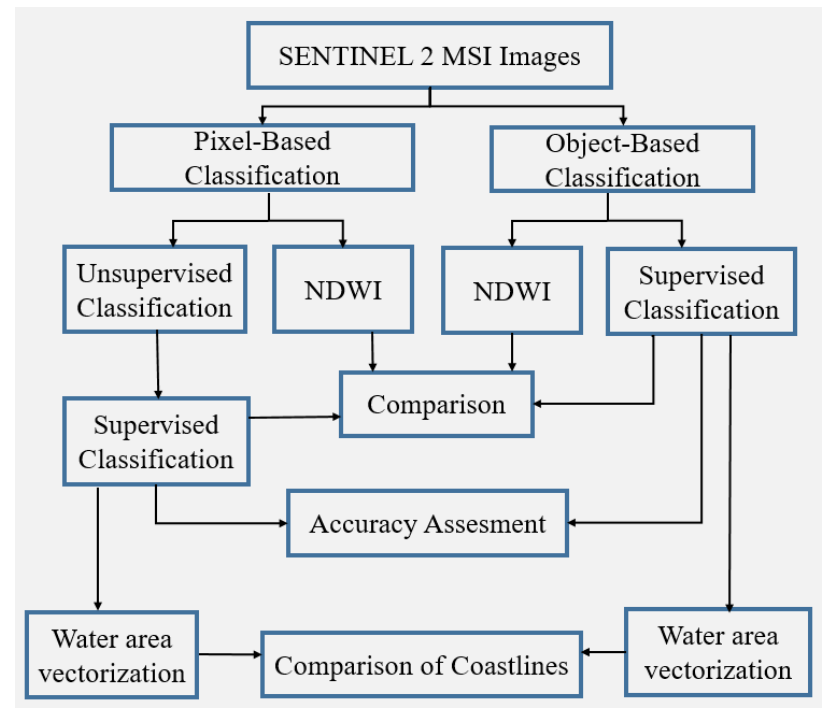

Figure 3. Flowchart of the study
Optical remote sensing satellites carry sensors that make use of visible, NIR, and SWIR regions to form images of the Earth's surface. Sensors record the electromagnetic radiation reflected or emitted by the Earth and its environment for subsequent analysis and extraction of information. Multispectral sensors generate multilayer spectral images that contain both the brightness and spectral (color) information. Each band gives a definite spectral signature of targets due to their difference in radiation, absorption, and reflectance properties (Prusty et al., 2017). In the study, six bands of Sentinel 2 MSI satellite images, Band 2 (blue), Band 3 (green), Band 4 (red), Band 8 (NIR), Band 11, and 12 (SWIR) were used. Statistical methods Iterative Self Organizing Data (ISODATA) and the Maximum Likelihood algorithm classifier were used to determine the water surface areas in the wetland. ISODATA (Iterative Self Organizing DATA) unsupervised classification method was applied first. ISODATA calculates the class means iteratively using minimum distance (Abbas et al., 2016). 300 clusters were obtained with ISODATA and every cluster was examined by drawing reflectance curves. 300 clusters were separated like water and non-water according to their spectral signatures. Water classes were also divided into 4 classes according to different reflections. The 300 clusters, separated like water and non-water, was used in the supervised classification. Maximum Likelihood algorithm was applied. The maximum likelihood classification is widely used for the classification of remotely sensed optical data. Maximum likelihood estimates of the parameters are computed, and the individual pixels are assigned to the class which maximizes the likelihood function of the data set (Strahler, 1980).

Object-based classification work on objects that are composed of many pixels, grouped in a meaningful way by the segmentation process. Then these objects are used instead of pixels as a classification object (Carleer and Wolff, 2006; Buyuksalih et al., 2009; Blaschke, 2010; Esetlili et al., 2018; Alganci, et al., 2018). Image segmentation is one of the most important steps in the object-based classification. In the segmentation process, three parameters, namely the scale parameter, the shape parameter, and the integrity parameter, are essential. The most effective parameter in these parameters is the scale parameter. First, the shape and the integrity parameters are kept fixed and the scale parameter is changed to find the value of the desired object. Then, the other parameters are changed with the scale parameter keeping fixed. This process was progressed until optimum segments were obtained. After multi-resolution segmentation, sample sites for each land cover class are identified. Then, statistics are defined to classify the image objects. Finally, the nearest neighbor method classifies objects based on their resemblance to the training sites, and thus the statistics are defined. This study aims to test and compare the above-mentioned classification algorithms for their ability to determine the wetland coastline.

\section{Results and Discussion}




\section{Results and Discussion}

\section{Pixel and Object-Based Classification}

Water surface areas obtained as a result of pixel and object-based classification are given in Table 1. As a result of pixel-based classification and object-based classification, it is seen that water surface areas are close to each other as shown in Table 1.

Table 1. Water Surface Areas

\begin{tabular}{|c|c|c|c|}
\hline Date & & ATION & Area (ha) \\
\hline March 28, 2018 & $\begin{array}{l}\text { Pixel-based } \\
\text { Pixel-based } \\
\text { Object-based }\end{array}$ & $\begin{array}{c}\text { Unsupervised_ISODATA } \\
\text { Hybrid (ISODATA+ML) } \\
\text { Supervised }\end{array}$ & $\begin{array}{l}747.63 \\
746.77 \\
740.69\end{array}$ \\
\hline June 28, 2018 & $\begin{array}{l}\text { Pixel-based } \\
\text { Pixel-based } \\
\text { Object-based }\end{array}$ & $\begin{array}{c}\text { Unsupervised_ISODATA } \\
\text { Hybrid (ISODATA+ML) } \\
\text { Supervised }\end{array}$ & $\begin{array}{l}702.59 \\
700.69 \\
705.28\end{array}$ \\
\hline Sep.29, 2018 & $\begin{array}{l}\text { Pixel-based } \\
\text { Pixel-based } \\
\text { Object-based }\end{array}$ & $\begin{array}{c}\text { Unsupervised_ISODATA } \\
\text { Hybrid (ISODATA+ML) } \\
\text { Supervised }\end{array}$ & $\begin{array}{l}113.85 \\
114.40 \\
116.55\end{array}$ \\
\hline Nov.11, 2018 & $\begin{array}{l}\text { Pixel-based } \\
\text { Pixel-based } \\
\text { Object-based }\end{array}$ & $\begin{array}{c}\text { Unsupervised_ISODATA } \\
\text { Hybrid (ISODATA+ML) } \\
\text { Supervised }\end{array}$ & $\begin{array}{l}649.19 \\
643.03 \\
657.17\end{array}$ \\
\hline March 18, 2019 & $\begin{array}{l}\text { Pixel-based } \\
\text { Pixel-based }\end{array}$ & $\begin{array}{l}\text { Unsupervised_ISODATA } \\
\text { Hybrid (ISODATA+ML) }\end{array}$ & $\begin{array}{l}770.15 \\
770.25 \\
\text { 7חo o }\end{array}$ \\
\hline
\end{tabular}

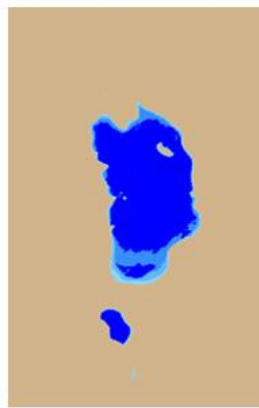

March 28,2018

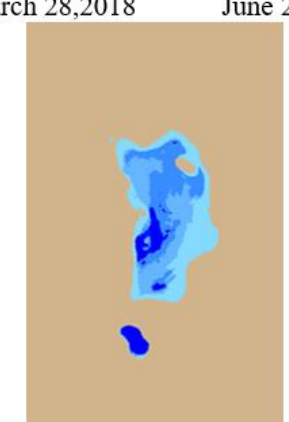

November 08,2018

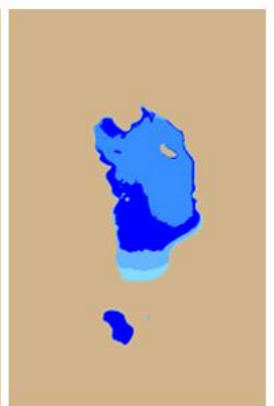

28,2018

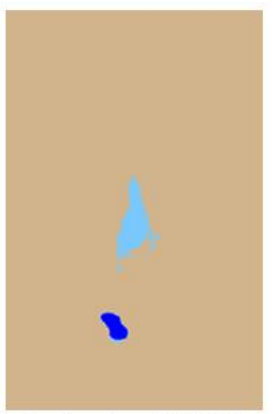

September 29,2018

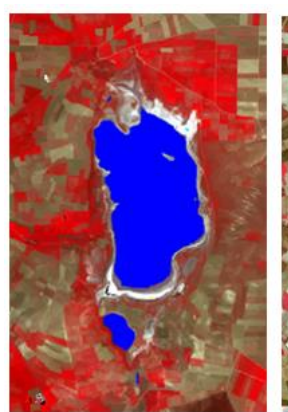

March 28,2018

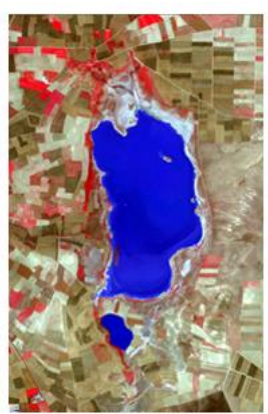

June 28,2018

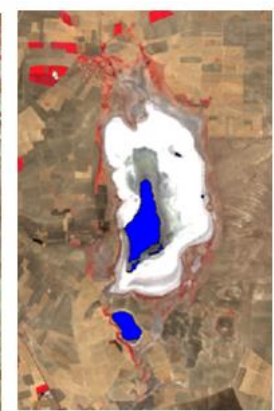

September 29,2018

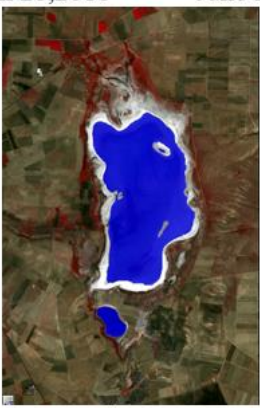

November 08,2018

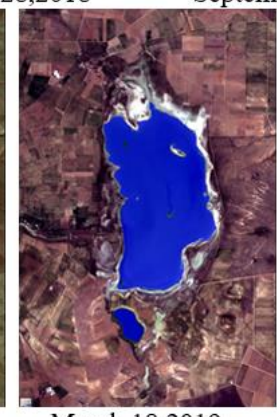

March 18,2019
Figure 5. Water surface areas with object-based classifications

The obtained water surface areas were converted to vector and the coastlines were compared. In Figure 6, the coastlines of each month obtained from the pixel-based and object-based classification methods are shown together. 

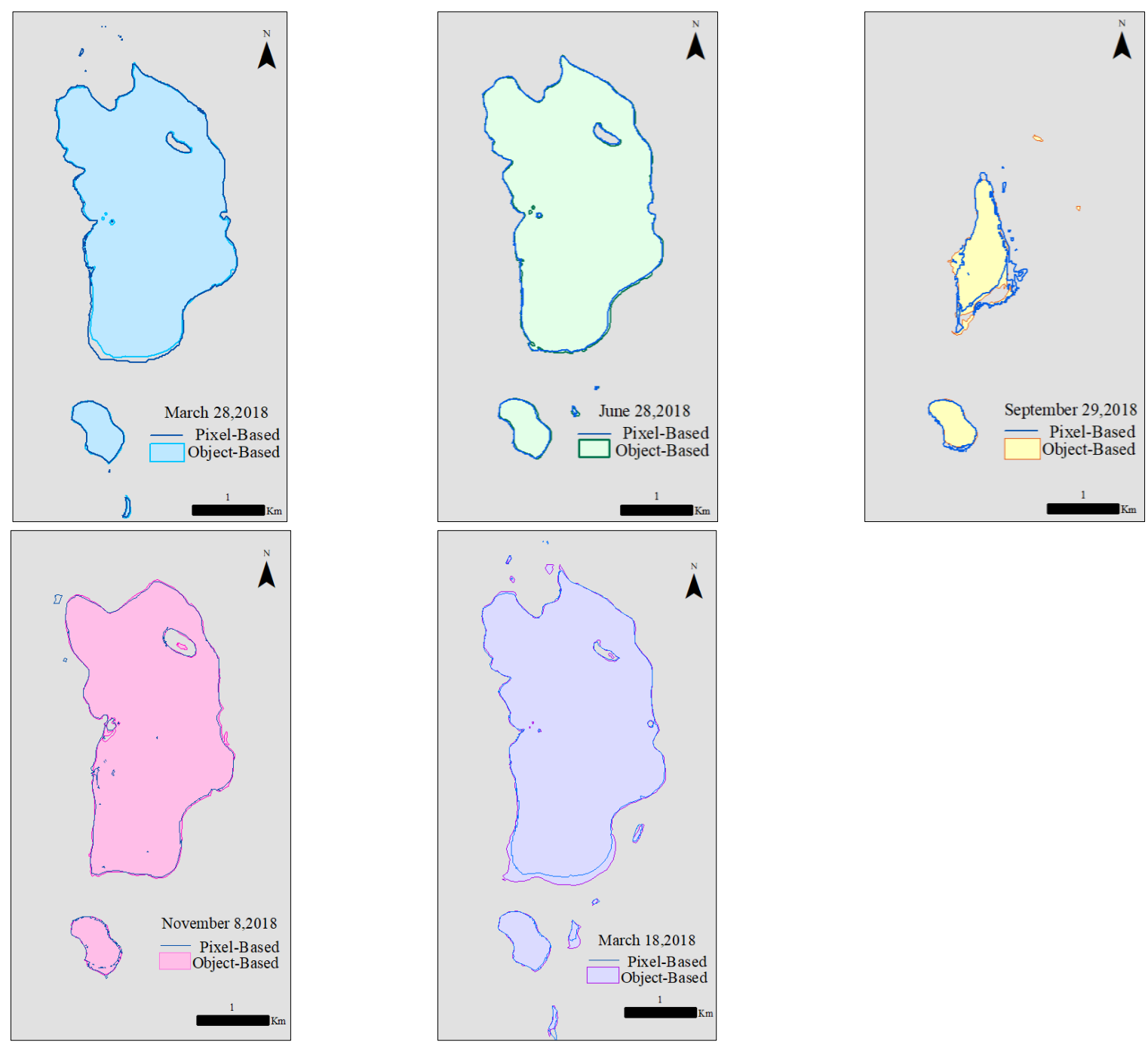

Figure 6. Coastlines from pixel-based and object-based classification

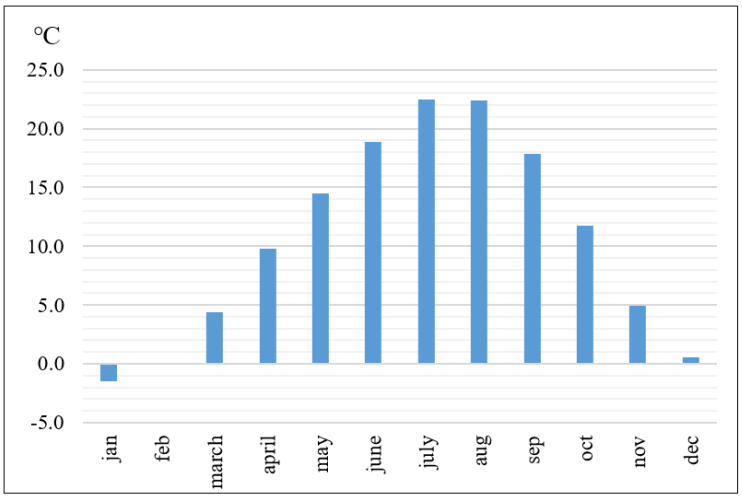

Figure 7. Average monthly temperatures from 1980 to 2017.

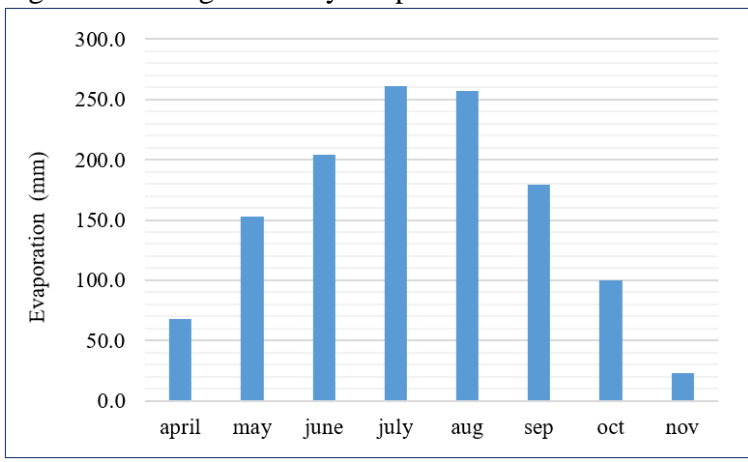

Figure 9. Average monthly evaporation from 1985 to 2011.

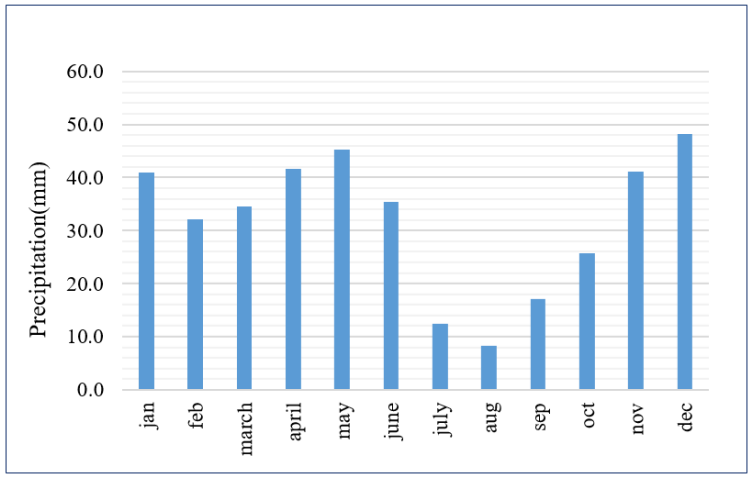

Figure 8. Average monthly precipitation from 1980 to 2017. 


\section{Evaluation of Meteorological Data}

Temperature, precipitation, and evaporation data obtained from Kulu meteorological station were evaluated and their monthly averages were taken and shown in Figure 7, Figure 8, and Figure 9 below, respectively.

Looking at the monthly average temperatures of the years from 1980 to 2017, it is seen that the hottest month is July with an average of $22.5 \mathrm{C}$ followed by August, June, and September, respectively. When the evaporation data for the period of 1985 to 2011 are examined, it is seen that the evaporation amounts are parallel to the temperature, as being $260.8 \mathrm{~mm}$ in July and $257 \mathrm{~mm}$ in August, followed by June and September. Besides, the time with the least rainfall in the summer months, having an average of precipitation as $8.3 \mathrm{~mm}$ in August, $12.5 \mathrm{~mm}$ in July, and $17 \mathrm{~mm}$ in September. In July, August, and September, precipitation/evaporation rates are 20.8, 30.95, and 10.5 respectively. The reason behind the inadequate water in the wetlands in September is the high evaporation rate and the usage of Kulu Creek for irrigation purposes during the summer months. In November, there is water seen in the area since irrigation season ends by midSeptember, and water can reach the area from the Kulu stream by the end of September.

\section{NDWI}

NDWI was applied to the pixel images and segmented images, to classify the images into two categories consisted of water and non-water objects. The water surface areas obtained from NDWI are shown with blue color and given in Figure 10.
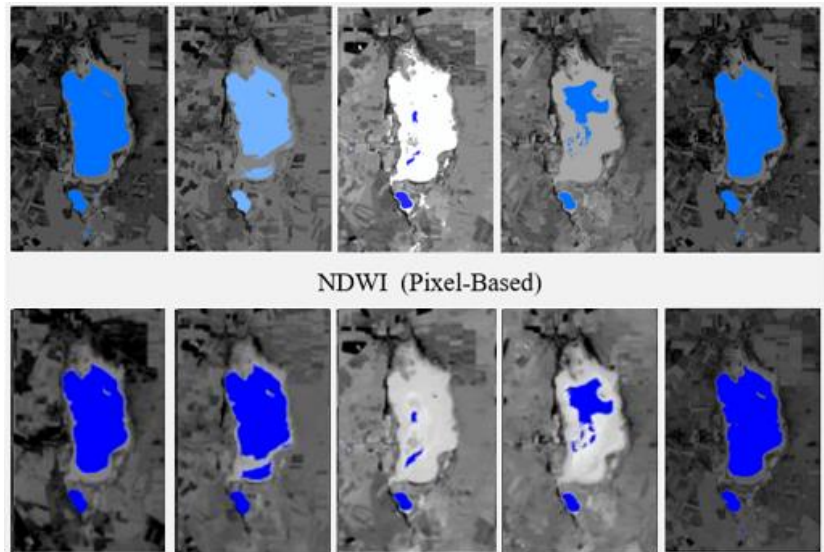

NDWI (Pixel-Based)
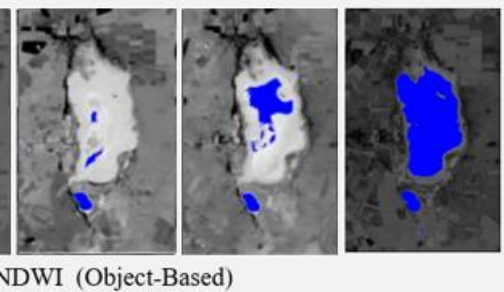

March 28,2018 June 28,2018 Sep 29,2018 Nov 8, 2018 March 18,2019 Figure 10. Pixel and object-based NDWI

Water surface areas obtained from NDWI are given in Table 2 with numerical values.

Table 2. NDWI results

\begin{tabular}{ccc}
\hline Date & NDWI & Water Area (ha) \\
\hline March 28, 2018 & Pixel-based & 707.17 \\
June 28, 2018 & Object-based & 705.56 \\
& Pixel-based & 642.71 \\
Sep. 29,2018 & Object-based & 646.15 \\
& Pixel-based & 41.87 \\
Nov. 08, 2018 & Object-based & 43.45 \\
& Pixel-based & 189.58 \\
March 18, 2019 & Object-based & 188.21 \\
& Pixel-based & 754.36
\end{tabular}

Table 3. Accuracy assessments of classifications

\begin{tabular}{cccc}
\hline Date & Classification & OA & Kappa \\
\hline March 28, 2018 & Pixel-based & 0.993 & 0.985 \\
& Object-based & 0.985 & 0.970 \\
June 28, 2018 & Pixel-based & 0.993 & 0.985 \\
Sep. 29,2018 & Object-based & 0.993 & 0.985 \\
Nov. 08, 2018 & Pixel-based & 0.993 & 0.943 \\
March 18, 2019 & Object-based & 0.985 & 0.892 \\
& Pixel-based & 0.963 & 0.922 \\
& Object-based & 0.940 & 0.877 \\
& Pixel-based & 0.993 & 0.985 \\
\end{tabular}

It is noted that the results of NDWI applied to pixelbased and object-based images are similar to each other. However, NDWI results are not very succeeding compared to the classification results. Comparing the water surface areas obtained by classification and NDWI techniques, the similarity was over $90 \%$ in March 2018, June 2018 and March 2019, whereas the similarity in September and November remained at $30 \%$. The reason for this deficiency, especially in September and November, is that the amount of water in the region is 
very shallow (maybe a few $\mathrm{cm}$ ) and the reflection of aquatic plants appears intensely in these areas.

\section{Accuracy Assessment}

Accuracy of the pixel-based and object-based supervised classifications results was evaluated with 200 randomly selected points. Overall accuracy (OA) and kappa values were determined and are shown in Table 3.

The results of the accuracy assessment applied to the classification results were over $90 \%$ as seen in Table 3 . The same randomly applied 200 points were used in each month for the classification. Based on objectoriented classification results, only Kappa statistics were below $90 \%$ in September and November. Looking at the outcome, usage of two classes as "water" and "the others" and the usage of randomly selected points are the major factor assessing the results. Although accuracy analysis yielded high accuracy results, for March 2018, the area corresponding to the lower part of the lake was classified as water in the pixel-based classification but in the object-based classification, it was stated as a nonwater area. When the results of March 2019 are examined, the non-water part in the pixel-based classification was determined as water in the objectbased classification. In the March 2018 image, the spectral reflections of the stated water areas in the pixelbased classification were examined at multiple points, and it resulted that the reflected area was surface water. Again, in March 2019, the areas determined as water in the object-based classification were observed to have plant reflection.

According to these results, it can be noted that the Pixelbased Maximum Likelihood classification made with clusters after creating a high number of clusters and checking the spectra of these clusters, gave better results for Sentinel 2 satellite image with a $10 \mathrm{~m}$ spatial resolution.

\section{Conclusion}

Remote sensing technology provides many advantages over the traditional methods in wetland study due to the capability to achieve a synoptic view with wide area coverage, the capability to carry out surveys during the desired period, and low cost. With this study, it has been observed that Sentinel 2 satellite images provide a useful tool for coastline extraction. Sentinel temporal satellite images are important data sources for coastal studies related to coastline change detection if spatial resolution is sufficient for the intended use.

The results show that significant changes in the coastline took place during a year. The highest amount of coastline displacement was observed in September. Low precipitation and high evaporation, the use of water for agricultural irrigation cause a large part of the shallow lake area to dry out.

It is seen that water surface areas determined by pixel and object-based classification methods using Sentinel 2 satellite images with $10 \mathrm{~m}$ of spatial resolution has given close results. However, differences are observed when the coastlines are examined. The NDWI results applied to pixel and object-based images are consistent with each other, however, conflicting with the classification results.

It is seen that NDWI has not given accurate results where the water level is extremely low and especially covered with mosses or aquatic vegetation. In determining wetland boundaries, it is stated that besides the using of NDWI, the use of Normalized Difference Pond Index (NDPI), Normalized Difference Turbidity Index (NDTI) and Normalized Difference Vegetation Index (NDVI) with appropriate thresholds can increase the accuracy.

In the accuracy analysis performed by random points, although high accuracy was obtained in both classification methods, it was seen that some of the areas which are non-water stated as water in object-based classification and the non-water areas stated as water. Since the water surface area changes from a few meters to a few cms in wetlands, accuracy analysis should be done by determining specific points especially in coastal areas with shallow water and in the swamp areas having a mixture of water and plants.

In further studies, usage of high spatial resolution satellite images or orthophoto images as the master data can be considered. The integration of aerial photographs with high-resolution imagery could further improve the accuracy of results and the coastline. Wetlands are dynamic systems; so especially in a study aiming to determine the coastal line in wetlands, spectroradiometer measurements and coordinate measurements must be simultaneous with the date on which satellite images are received. Thus, the results from high-spatial-resolution images and mid-spatial resolution images can be compared to determine whether the pixel-based classification or the object base classification is more appropriate.

\section{References}

Abbas, AW., Minallh, N., Ahmad, N., Abid, SAR., Khan, MAA. (2016). K-Means and ISODATA clustering algorithms for land cover classification using remote sensing. Sindh University Research Journal-SURJ (Science Series), 48(2), pp. 315-318.

Alesheikh, AA., Ghorbanali, A., Nouri, N. (2007). Coastline change detection using remote sensing. International Journal of Environmental Science \& Technology, 4(1), pp. 61-66.

Alganci, U., Sertel, E., Kaya, S. (2018). Determination of the olive trees with the object-based classification of Pleiades satellite image", International Journal of Environment and Geoinformatics (IJEGEO) 132139.

Bayram, B., Bayraktar, H., Acar, U. (2004). Coastline change detection using CORONA, SPOT and IRS 1D images Int. Arch. Photogramm. Remote Sens., 35, 437-441.

Blaschke, T., Hay, G. J., Weng, Q., Resch, B. (2011). Collective sensing: Integrating geospatial 
technologies to understand urban systems- an overview. Remote Sensing, 3(8), 1743-1776.

Burak, S. A., Dogan, E., Gazioglu, C. (2004). Impact of urbanization and tourism on coastal environment. Ocean \& Coastal Management, 47, 515-527.

Buyuksalih, I., Gazioglu, C., Buyuksalih, G., Muftuoglu, AE., Demir, V. (2009). The object-oriented image analysis method of using in Coastal Zone, The Ninth International Conference on the Mediterranean Coastal Environment, 1-10.

Carleer, AP., Wolff, E. (2006). Region-Based classification potential for land cover classification with very high spatial resolution satellite data, in Proceedings of 1st International Conference on Object-based Image Analysis, Austria, Vol. XXXVI, ISSN 1682-1777, 4-5.

Celik, OI., Gazioglu, C. (2020). Coastline Difference Measurement (CDM) Method, International Journal of Environment and Geoinformatics (IJEGEO), $7(1): 1-5$.

Doganyigit, R. (2016). Works on Lakes and Wetlands. http://www.suyonetimi.gov.tr/ (Turkish)

Dronova, I., Gong, P., Wang, L. (2011). Object-based analysis and change detection of major wetland cover types and their classification uncertainty during the low water period at Poyang Lake, China. Remote Sensing of Environment, 115(12), 3220-3236.

Esetlili, MT., Bektas Balcik, F., Balik Sanli, F., Ustuner, M., Kalkan, K., Goksel, Ç., Gazioglu, C. Kurucu, Y. (2018). Comparison of Object and Pixel-Based Classifications for Mapping Crops Using Rapideye Imagery: A Case Study of Menemen Plain, Turkey, International Journal of Environment and Geoinformatics (IJEGEO), 5(2), 231-243.

Guariglia, A., Buonamassa, A., Losurdo, A., Saladino, R., Trivigno, M. L., Zaccagnino, A., Colangelo, A., (2006). A multisource approach for coastline mapping and identification of shoreline changes. Annals of geophysics, 49(1).

Haibo, Y., Zongmin, W., Hongling, Z., Yu, G. (2011). Waterbody extraction methods study based on RS and GIS. Procedia Environmental Sciences, 10, pp. 2619-2624.

Kalkan, K., Bayram, B., Maktav, D., Sunar, F. (2013). Comparison of support vector machine and objectbased classification methods for coastline detection. International Archives of the Photogrammetry, Remote Sensing and Spatial Information Sciences, 7, $\mathrm{W} 2$.

Kalkan, K., Maktav, D., Bayram, B. (2019). Shoreline Extraction From Cloud Removed Landsat 8 Image: Case Study Lake Ercek, Turkey, Mathematical Modeling of Real World Problems, Interdisciplinary Studies in Applied Mathematics, 37-54.

Kaplan, G., Avdan, U. (2017). Object-based water body extraction model using Sentinel-2 satellite imagery. European Journal of Remote Sensing, 50(1), pp. 137143.

Kaya, H., Ertek, T., Gazioğlu, C. (2019). Geomorphological Features of Terkos Lake. International Journal of Environment and
Geoinformatics, 6(2), 192-205. DOI: 10.30897/ijegeo.569748.

Li, X., Damen, M. C. (2010). Coastline change detection with satellite remote sensing for environmental management of the Pearl River Estuary, China. Journal of Marine Systems, 82, pp. 54-61.

Lillesand, T., Kiefer, R. W. Chipman, J. (2014). Remote sensing and image interpretation. John Wiley \& Sons.

McFeeters, S.K. (1996). The use of the normalized difference water index (NDWI) in the delineation of open water features. International Journal of Remote Sensing, 17(7), 1425-1432.

Prusty, B.A. K, Chandra, R., Azeez, P.A. (2017). Wetland Science.Springer.

Rasuly, A., Naghdifar, R. Rasoli, M. (2010). Monitoring of Caspian Sea coastline changes using objectoriented techniques. Procedia Environmental Sciences, 2, pp. 416-426.

Shang, K., Zhang, X., Dong, Z. Zhang, X. (2012). Information extraction method on coastal wetland using TM data: A case study in Dongying, Shandong, China. In 2012 Second International Workshop on Earth Observation and Remote Sensing Applications, 77-81.

Strahler, AH., 1980. The use of prior probabilities in maximum likelihood classification of remotelysensed data. Remote Sensing of Environment, 10, $135-163$.

URL1:https://www.sentinel-hub.com/eoproducts/ndwinormalized-difference-water-index 